\title{
Economic Reforms and Growth Experiences: A Comparative Study of China and Sri Lanka
}

\author{
P.M. Bandula Jayathilake \\ Department of Business Management, Faculty of Management Studies, \\ Rajarat University of Sri Lanka, Mihintale, Sri Lanka \\ Corresponding author (e-mail): bandulapmb@yahoo.com
}

\begin{abstract}
China has achieved extraordinary economic growth and development in last three decades since launch of open economic policy in 1978. Sri Lanka restructured its economy in 1977 as well, with aspiration of achieving sustainable economic growth and development. However, the growth performance of Sri Lanka since the initiation of the reforms has been relatively low and falling behind on many of fronts relative to the Chinese performance indicators, whereas the initial characteristics of the two countries and reforms are mostly comparable. This paper basically aimed to investigate the factors influencing the creation of the gap in growth performance between China and Sri Lanka over the past three decades after their economic reforms. The findings show that attraction of foreign direct investment, governance related factors and approaches used in the post reforms period are more vital in driving divergence in growth performance between the two countries.
\end{abstract}

Keywords: China, Economic Growth, Economic Reforms, Sri Lanka

\section{Introduction}

China and Sri Lanka have undertaken fairly extensive economic reforms during past three decades initiating in 1978. At the time the economic reforms were introduced, both countries have faced similar types of economics crisis, particularly, low industrial and agriculture production, low per capita income and social conditions. These frustrating conditions influenced and helped the dramatic restructuring of their economies. 
Furthermore, the reforms in China became possible after the death of their paramount leader, Mao Zedong who was steeped in conventional socialist ideology and had dominated the political systems for decades prior to his death. The United Nation Party's defeat of the left learning Sri Lanka Freedom Party government in 1977 facilitated to craft drastic economic reforms in Sri Lanka. Since the adoption of economic reforms in 1978, China has witnessed impressive economic growth with social progress and poverty reduction. Sri Lanka, being a smaller country compared to China and comparable in terms of human capital, has experienced modest economic performance since opening up its economy to the world. Figure 1 shows the relationship between GDP growth rates of China and Sri Lanka over the past three decades after their economic reforms implementation. It clearly shows that both countries followed very similar growth pattern with keeping a notable gap. This significant divergence raises the question what has caused this sizeable gap in the growth pattern between China and Sri Lanka. This study aims to investigate the similarities between China and Sri Lanka in the context and nature of their economic reforms and the factors which caused the gap in growth performance between the two countries to increase.

This paper starts with a review of literature that relates to economic growth divergence, followed by a brief presentation of the study methodology. Next two sections are devoted for discuss the study results and present the conclusion of the study along with policy recommendations.

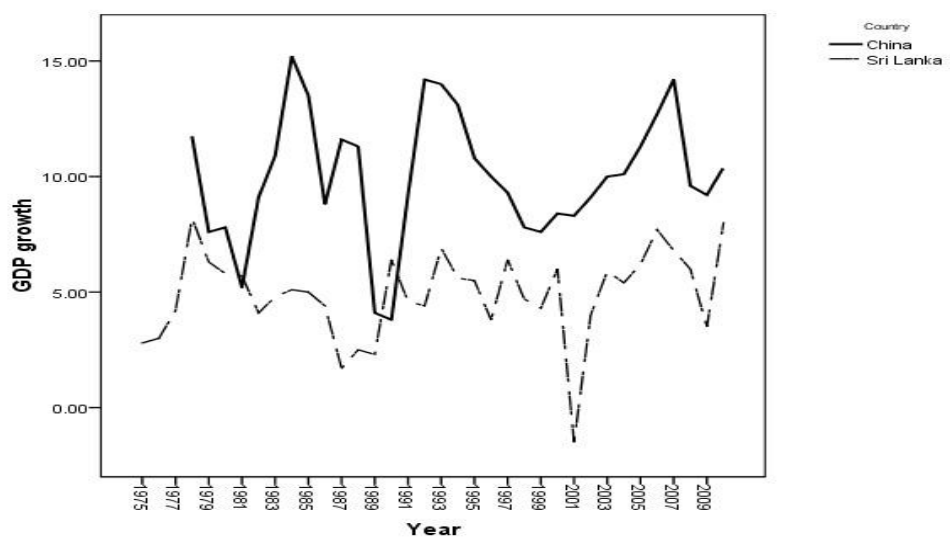

Figure 1-1 GDP Growth of China and Sri Lanka (1978 - 2010)

\section{Literature}

There are numerous studies examining the relationship between openness and economic performance in the recent literature. Greenaway et al (1998), Yue, (1999) and Pomfret and Anderson (1997) find that Foreign Direct Investment (FDI) and international trade contribute positively to economic growth. FDI plays vital role in technology transfers and spill over while international trade drives international competition. With regard to growth differences between regions, literature has introduced several factors conducive to creation of such a difference and divergence. The most influential factors are geography, climate and economic policies. 
Kanbur and Zhang (2005) demonstrated that regional inequalities could be explained by factors like openness and decentralization. Krishna (2004) and Basu (2006), among the others, revealed that economic policies, geographic and institutional factors at the state levels could explain deferential level of economic growth and performance. Similarly, Aghion et al (2008) argue that benefits from economic liberalization in different regions differ because of initial level of technology and institutional factors.

In addition to that Barro and Martin (1991) put forward four vital factors in explaining the variation in economic growth across countries. Those factors include low level of income, basic human capital, institutions and governance related issues. According to them, the low level of income has negative impact on growth. This type of behavior is known as the conditional convergence effect. Basic human capital is supposed to have a positive impact on growth. According to Barro and Martin (1991) and Claessens and Laeven (2003), institutions include the rule of law, property rights, corruption and political stability and better maintenance of rule of law and property rights which have a positive effect on growth. At the same time corruption and political instability have a negative effect on growth. Openness, share of investment in GDP, investment in transport and communication, development of financial system and technology diffusion and innovation are considered as one category of governance related factors which positively impact on the growth (Sachs and Warner, 1997; Easterly and Rebelo, 1993). Market distortions, inflation, budget deficits and share of government spending in GDP, on the other hand, are considered as the second category of variables which reflect the institution and negatively affect economic growth (Sachs and Warner, 1997; Barro and Martin, 1991). All of the evidence shows that effective economic policy making has to be coupled with robust institutional arrangements to sustain economic growth and social development.

Thorbecke and Wan (2004) developed a framework to explain divergence on growth specially related to East Asia. The framework consists of six elements putting emphasis on agriculture development and primary education, macroeconomic stability, opening up the economy to the world emulation of technology leaders, advantage of intra East Asian connections and unused growth potential.

\section{Methodology}

Due to the intricate nature of economic growth and development concepts it is not surprising that various factors influence it. Since main objective of the study is to investigate the growth divergence between China and Sri Lanka after the economic reforms, methodology used in this study shows two clear phases. In first phase, growth patterns of two countries were identified with using GDP growth in last three decades. Thereafter, the factors influencing the divergent growth were analyzed with factors proposed by Barro and Martin (1991) and the framework proposed by Thorbecke and Wan (2004). 


\section{Results and discussion}

Both China and Sri Lanka started their economic reforms in the same year on the ground of the economies dominated by the agriculture sectors and socialistic characteristics followed societies. During their prereforms period the two countries made extraordinary efforts to build their socialist economies but rather than achieving success, they experienced desperate failure. In this period, economic growth rates in the two countries were well below $4 \%$ and agricultural and industrial production were too low, and people's living standard had not increased in significantly.

With regard to the initial level of income, China's per capita income in 1977 was \$ 184 which slightly lower than Sri Lanka ( $\$ 199$ ) by $\$ 15$. According to Brro and Martin (1991), conditional convergence effect was in favor for China in initial stage of economic reforms. In the initial stage of the reforms, both countries were in similar background on basic human capital. As shown in Table 1, China and Sri Lanka had comparable basic measures relating to health and education. However, in every measurement aspect Sri Lanka was in a more favorable position than China, given that basic human capital positively impacts the economic growth.

\begin{tabular}{lcc}
\hline \multicolumn{1}{c}{ Indicator } & \multicolumn{2}{c}{ Country } \\
\cline { 2 - 3 } & China & Sri Lanka \\
\hline Life expectancy at Birth (in Years) & 67 & 68 \\
\hline Adult literacy (\% of total) & 67 & 85 \\
\hline $\begin{array}{l}\text { Infant mortality rate (per 1000 } \\
\text { people) }\end{array}$ & 51 & 43 \\
\hline GDP per capita US\$ & & \\
\hline
\end{tabular}

Table 4-1 Basic Development Indicators in 1977

Literature identified institutions as a vital factor encouraging economic development and explaining the variations in economic growth performance across the countries. Voice and accountability, political stability and absence of violence, rule of law, control of corruption and regulatory quality have been incorporated in the World Bank Governance Indicators composed by Kaufmann et al (2007). Table 2 shows the averages of each of the indicators for the period of 1996 to 2010. With regard to political stability and absence of violence, the likelihood that the government will be destabilized by unconstitutional or violent means, including terrorism, China is clearly in better position when compared with Sri Lanka that has a score of 1.34. Since political stability has a solid impact on investment and growth, this factor is in favor for China over Sri Lanka in connection with economic performance. According to the measure for Rule of law, China is 
in negative zone while Sri Lanka has recorded a positive figure. These figures indicate that confidence in and abiding by the rules of society, including the quality of contact enforcement, property rights, the police, and the courts, as well as the likelihood of crime and violence are threats for both countries to achieve their economic growth and sustainability.

\begin{tabular}{|c|c|c|}
\hline Indicator & China & Sri Lanka \\
\hline \multicolumn{3}{|l|}{ Governance Indicators (1996 -2010 Average) } \\
\hline Political Stability and absence of violence & -0.51 & -1.34 \\
\hline Voice and Accountability & -1.53 & -0.31 \\
\hline Government Effectiveness & -0.01 & -0.23 \\
\hline Regulatory Quality & -0.25 & -0.07 \\
\hline Rule of Law & -0.41 & 0.11 \\
\hline Control of Corruption & -0.47 & -0.24 \\
\hline Fixed Investment ( $\%$ of GDP) -2008 & 40.20 & 30.00 \\
\hline Per capita income in 2010 - US\$ & 4382 & 2435 \\
\hline Global Competitive Index & 4.07 & 4.03 \\
\hline Innovative Capability Index - 2011 & 18.10 & 15.10 \\
\hline Gross domestics savings ( $\%$ of GDP) - 2010 & 52.00 & 19.00 \\
\hline Index of economic freedom - 2010 & 51.00 & 54.60 \\
\hline Foreign Direct Investment (US\$ bn) - 2010 & 90.90 & 0.40 \\
\hline Human Development Index & 0.682 & 0.686 \\
\hline
\end{tabular}

Table 4-2 Development Indicators

As rule of law has a negative impact on growth performance divergence between the two countries has not been influenced by rule of law. Control of corruption in developing countries has been identified as a severe problem in achieving their growth targets. Both China and Sri Lanka are in the negative zone of the World Bank's control of corruption indicators. The problem of corruption has a high impact on the Chinese economy 
in comparison to Sri Lanka. It reveals that there is no evidence to regard control of corruption as a significant factor in making growth divergence between China and Sri Lanka. Regulatory quality is an important indicator that reflects the institution variable and it entails the ability of the government to make sound policies and regulations that enable and promote private sector development. With regard to this measure, both countries are in negative zone, with China being $(-0.25)$, and Sri Lanka being $(-0.07)$. The gap between China and Sri Lanka on the measure implies that regulatory quality has made no impact on the growth divergence between the two countries. Furthermore, voice and accountability cannot be considered as a factor which created growth divergence between the two countries as China has recorded higher negative values $(-1.53)$ over Sri Lanka(-0.31)fortheindicator.

Although both countries are in negative zone with respect to the government effectiveness, China $(-0.01)$ has witnessed favorable signs over Sri Lanka (-0.23). Furthermore, China has recorded significant positive signs over Sri Lanka on fixed investment as a percentage of GDP, global competitive index, innovative capacity index and gross domestic savings (see the table 2). These factors, therefore, can be considered as the significant divers in making growth divergence between China and Sri Lanka. Governance related factors including the leadership's commitment to reform, government effectiveness, government share of total fixed investment, control of inflation, industry policy, innovative capacity building and openness are significant determinants which speed up a nation's growth and development. According to the Index of Economic Freedom, Sri Lankan economy (54.6) is more open to the World compared to China (51.1). Therefore, openness has not made any impact on the growth divergence between the two countries.

The most prominent feature of China's economic success is attraction of FDI. 1n 1978, there was little FDI in China. In 2010, China became the one of largest recipients of FDI by receiving $\$ 90.9$ billion. Sri Lanka continuously failed to raise the inflows of FDI just receiving $\$ 0.4$ billion in 2010 . The endogenous growth theory suggests that investment in human capital is as important as physical investment. Accumulation of human capital is reflected in a number of areas, particularly in health and education. Improvement of people's health has led to a significant increase in life expectancy and a large reduction in child and infant mortality. As both countries share comparable human capital features (see Table 2), human capital has made no contribution in making growth divergence between the two countries.

\section{Conclusion}

This paper aimed to investigate the factors that influence the growth divergence between China and Sri Lanka after their economic reforms in 1978. China has achieved tremendous economic and social progress over the past three decades as a result of their development strategy including attraction of FDI, gradual openness, export push and financial market reforms. However, economic reforms in Sri Lanka have been characterized by political instability, lack of transference and blurred vision. The paper concludes that divergence in growth performance between China and Sri Lanka is mainly caused by factors including the 
attraction of FDI, government effectiveness and governance related factors. The paper also highlights the neediness of both countries' attention toward the political stability and absence of violence, control of corruption, regulatory quality and rule of law for achieving sustainable economic growth and development.

\section{References}

- Aghion P., Burgess R., Redding S., Zilibotti F, (2008), The unequal effects of liberalization: Theory and evidence from India. American Economic Review, vol.8, no. 4, pp. 1397-1412

- Barro R., Martine X.S. (1991), Economic growth and convergence across the United States. National Bureau of Economic Research working paper, July

- Basu S.R., (2006), Economic growth, well being and governance under economic informs: Evidence from Indian states. Journal of World Economic Review, vol. 1, no. 2, pp. 127-149

- Claessens S., Laeven L., (2003), Financial development, property rights and growth. The Journal of Finance, vol. 58, no. 6, pp. 2410-2436

- Easterly W., Rebelo S., (1993), Fiscal policy and economic growth. Journal of Monetary Economics, pp. $417-458$

- Greenaway D., Morgan C.W., Wright P., (1998), Trade liberalization and growth in developing countries: some new evidence. World Development, vol. 25, pp.1885-1892

- Kanbur R. Zhang X. (2005), Spatial inequality in education and health care in China. China Economic Review, vol. 16, pp. 189-204

- Kaufmann D, Kraay A., Mastruzzi M. (2007), Governance matters VI: Governance indicators for 1996-2006. World Bank Policy Research Paper, pp. 4280

- Krishna K.L. (2004), Patterns and determinants of economic growth in India. Working Paper, 144. CRIER. New Delhi

- Pomfret R., Anderson K.H. (1997), Uzbekistan: Welfare impact of slow transition. World Institute for Development Economic Research, pp. 135

- Sachs J.D., Warner A.M., (1995), Economic reforms- the process of global integration. Brookings Papers on Economic activity, vol. 1, pp.1-118

- Thorbecke E., Wan H., (2004), Revisiting East Asia's development model. Cornell Conference on the Seventy Five Years of Development, Ithaca, May 2004 